\title{
ANALISIS KORELASI, REGRESI DAN EVALUASI KARAKTER MORFOLOGI 24 AKSESI KAPAS (Gossypium sp.)
}

\section{Correlation and Regression Analysis and Morphological Character Evaluation of 24 Cotton (Gossypium sp.) Accessions}

\author{
Taufiq Hidayat RS $^{1 *}$, Andy Soegianto ${ }^{2}$, dan Putri Nurul Aini \\ ${ }^{1}$ Balai Penelitian Tanaman Pemanis dan Serat, Malang, Jawa Timur \\ 2 Jurusan Budidaya Pertanian, Fakultas Pertanian, Universitas Brawijaya, \\ *Alamat korespondensi: hidayat.taufiq87@gmail.com
}

\begin{abstract}
ABSTRAK
Salah satu upaya untuk meningkatkan produksi kapas adalah dengan memanfaatkan varietas unggul yang berproduksi tinggi dan bermutu serat baik. Tujuan penelitian ini untuk mengetahui bentuk dan keeratan hubungan antar komponen hasil sebagai penentu kriteria seleksi, serta mengevaluasi aksesi-aksesi kapas yang memiliki karakter unggul dan diduga dapat digunakan sebagai tetua dalam perakitan varietas kapas yang baru. Penelitian dilaksanakan pada Maret hingga Desember 2018 di Kebun Percobaan Karangploso, Balai Penelitian Tanaman Pemanis dan Serat, Malang. Metode penelitian menggunakan rancangan acak kelompok dan uji lanjut Tukey (Beda Nyata Jujur) melalui program SPSS. Hasil penelitian menunjukkan karakter jumlah cabang generatif dan jumlah buah memiliki koefisien korelasi dan regresi yang nyata dan positif terhadap bobot kapas berbiji. Jumlah cabang generatif dan jumlah buah dapat digunakan sebagai seleksi untuk memperoleh aksesi kapas yang berproduksi tinggi dan bermutu serat baik. Evaluasi karakter morfologi ada 11 aksesi yang terseleksi berdasarkan variabel panjang serat, yaitu KI 38, KI 80, KI 134, KI 240, KI 320, KI 489, KI 500, KI 629, KI 689, KI 693 dan KI 711.
\end{abstract}

Kata kunci: karakter morfologi, kriteria seleksi, serat, kapas

\section{ABSTRACT}

Cotton productivity can be increased by usng the superior variety that produce high quality and good fiber. The purpose of this study was to determine the shape and closeness of the relationship between the yield and yield components as determinants of selection criteria, and to evaluate cotton accessions that have superior character and can be used as a source of parents for the assembly of new cotton varieties. The research was conducted start from in March to December 2018 at the Karangploso experimental garden in the Indonesian Sweetener and Fiber Crops Reasearch Institute, Malang. The research method used Randomized Block Design and significant test with Tukey (Honestly Significantly Difference) using the Statistical Package for the Social Sciences (SPSS) program. The results showed that the number of generative branches and number of fruits had a correlation coefficient and a real and positive correlation to the weight of seed cotton. The number of generative branches and number of fruits can be used as a selection to obtain accessions of cotton that produce high quality and good fiber. Evaluation of morphological characters showed that there were 11 accessions potential to be used as the parents for producing new superior variety. These 11 accessions were KI 38, KI 80, KI 134, KI 240, KI 320, KI 489, KI 500, KI 629, KI 689, KI 693 and KI 711.

Keywords: morphological character, selection criteria, fiber, cotton

\section{PENDAHULUAN}

Kapas (Gossypium sp.) merupakan komoditas tanaman semusim sebagai penghasil utama serat dari buah yang digunakan sebagai bahan baku utama dalam pemenuhan kebutuhan industri tekstil di Indonesia. Komposisi kimia serat kapas menurut Nurnasari dan Nurindah (2017), memiliki kandungan selulosa tinggi sebesar 98,06\% dan menurut Björquist et al. (2018), limbah kapas dari fuzzy atau bulu halusnya dapat dijadikan pulp dan digunakan sebahai bahan baku serat. Kebutuhan konsumsi tekstil di Indonesia mengalami peningkatan 
setiap tahunnya sebesar 10.000 ton dari tahun 2015-2017 (Abdi et al., 2017). Berdasarkan data Direktorat Jenderal Perkebunan (2016), kebutuhan kapas nasional tahun 2016 mencapai 517.079 ton/tahun, produksi kapas dalam negeri hanya mampu memenuhi sebesar 6,1\% yaitu 31.305 ton/tahun. Berdasarkan data Pusdatin (2015), proyeksi permintaan kapas pada tahun 2019 mencapai 762.296 ton dengan defisit 762.103 ton. Hal ini disebabkan karena masih terbatasnya varietas unggul kapas yang resisten terhadap hama dan penyakit tanaman.

Salah satu cara untuk meningkatkan produksi kapas ialah melalui perakitan varietas unggul. Pemanfaatan plasma nutfah melalui pemuliaan tanaman kapas memiliki tujuan untuk mendapatkan potensi hasil tinggi, kualitas mutu baik, tahan hama, berumur genjah dan bersifat adaptif. Karakter pada tanaman merupakan faktor penting dalam perakitan varietas unggul yang mungkin dapat digunakan sebagai indikator seleksi aksesi kapas. Oleh karena itu, hubungan antar karakter tanaman memiliki peran penting dalam program pemuliaan tanaman. Analisis regresi dan korelasi antar karakter dapat digunakan untuk mengetahui hubungan antar karakter tersebut.

Hubungan antar karakter memberikan hasil yang dapat memprediksi perubahan yang terjadi pada satu karakter yang diikuti perubahan karakter terkait, yang digunakan untuk mengevaluasi dan memilih genotipe yang diinginkan. Novrika dan Herison (2016) melaporkan bahwa karakter tinggi tanaman dan jumlah biji per malai berkorelasi positif erat terhadap dengan hasil bobot biji per rumpunnya sehingga karakter tersebut dapat digunakan sebagai kriteria seleksi untuk memperoleh genotipe yang diinginkan. Korelasi sederhana dibagi menjadi fenotipe (yang dapat langsung diamati), genotipe (hubungan yang melekat antar karakter) dan lingkungan (deviasi lingkungan bersama-sama dengan komponen ragam genetik nonaditif). Metode ini sangat bermanfaat dalam program pemuliaan tanaman untuk mengetahui ada tidaknya hubungan antar karakter terhadap karakter utama yaitu komponen hasil sehingga berguna untuk memperbaiki respon ikutan (correlated respon) (Lelang, 2017). Prabowo dan Djoar (2014) menyatakan bahwa karakter yang berkorelasi tinggi terhadap hasil dapat berperan sebagai kriteria seleksi untuk memperoleh tanaman dengan potensi hasil tinggi.

Analisis regresi merupakan teknik analisa yang digunakan untuk memprediksi nilai-nilai dari satu atau lebih karakter terikat akibat adanya pengaruh dari satu atau lebih karakter bebas. Terdapat dua teknik regresi, yaitu regresi linier sederhana dan regresi linier berganda. Regresi linier 
sederhana merupakan analisa yang digunakan untuk mengestimasi nilai koefisien yang dihasilkan dari persamaan linier satu karakter bebas sehingga dapat diketahui besarnya pengaruh karakter bebas terhadap karakter terikat dan memprediksi besarnya karakter terikat melalui pengaruh dari karakter bebas. Pengetahuan mengenai besarnya hubungan antara hasil dan komponen-komponennya sangat membantu dalam mengkaji sebaran komponen yang berbeda terhadap hasil (Mahajan et al., 2011).

Melalui penentuan analisis korelasi dan regresi, maka diperoleh karakter tanaman yang dapat dipertimbangkan dan digunakan sebagai salah satu indikator dasar kriteria seleksi dalam mendukung program pemuliaan yang dilakukan. Sumartini et al., (2010), memperoleh aksesi dengan mutu serat tinggi berumur genjah, namun rentan hama Amrasca biguttula berdasarkan karakter komponen hasil. Indrayani dan Sumartini (2012), memperoleh aksesi yang berpotensi sebagai materi genetik unggul dalam perakitan varietas kapas tahan $A$. biguttula dan Helicoverpa armigera karakter kerapatan bulu daun dan kelenjar gosipol. Kulaz (2012) melaporkan bahwa jumlah cluster per tanaman dan jumlah polong per tanaman berkorelasi fenotipik positif sangat nyata pada umur awal berbunga dan umur awal panen terhadap bobot polong per tanaman. Yamin (2014) memperoleh karakter seleksi yang berkorelasi positif dan kuat yaitu jumlah biji malai utama sebagai kriteria seleksi gandum berproduksi tinggi di dataran menengah. Permata et al., (2015) memperoleh lima karakter yang korelasi positif nyata terhadap hasil dan dapat digunakan sebagai indek seleksi terhadap komponen hasil. Kusuma dan Tahir (2017) memperoleh tetua kapas yang berumur genjah berdasarkan karakter jumlah cabang monopodial, jumlah cabang simpodial, tinggi tanaman, umur berbunga, umur buah merekah, umur panen, dan sensitivitas terhadap fotoperiodisitas. Umufatdilah dan Adiredjo (2019) melaporkan bahwa karakter diameter batang memiliki nilai koefisien korelasi dan regresi yang paling tinggi yaitu 0,901 dan 0,812 terhadap hasil tanaman kenaf.

Tujuan dari penelitian ini untuk mengetahui bentuk dan keeratan hubungan antar komponen hasil sebagai penentu kriteria seleksi, serta mengevaluasi aksesiaksesi kapas yang memiliki karakter unggul dan diduga dapat digunakan sebagai tetua dalam perakitan varietas kapas yang baru.

\section{METODE PENELITIAN}

Penelitian dilaksanakan di Kebun Percobaan Karangploso, Balai Penelitian Tanaman Pemanis dan Serat, Malang, Jawa Timur. Penelitian dilaksanakan pada bulan Maret sampai Desember 2018. Materi 
genetik yang digunakan yaitu 24 aksesi tanaman kapas yang terdiri atas KI 629, KI 5, KI 38, KI 42, KI 80, KI 95, KI 106, KI 109, KI 124, KI 134, KI 188, KI 225, KI 286, KI 240, KI 241, KI 301, KI 320, KI 489, KI 494, KI 500, KI 502, KI 689, KI 693, KI 711 dan satu varietas pembanding yaitu Kanesia 19.

Metode penelitian menggunakan rancangan acak kelompok yang diulang sebanyak tiga kali. Satu satuan unit percobaan terdiri dari satu baris aksesi dengan jumlah tanaman sebanyak 40 tanaman dan jarak tanam antar baris adalah $150 \mathrm{~cm} \times 25 \mathrm{~cm}$. Pengamatan dilakukan melalui pengambilan data kuantitatif dan kualitatif pada 10 tanaman sampel setiap aksesi yang diambil secara acak.

Karakter yang bersifat kualitatif yang diamati meliputi bentuk tanaman, warna batang, bentuk daun, warna petal, bentuk buah, bentuk ujung buah, warna buah, warna serat kapas dan warna biji berkabu. Karakter kuantitatif yang diamati yaitu komponen hasil meliputi tinggi tanaman, jumlah cabang vegetatif, jumlah cabang generatif, jumlah bulu daun, umur awal berbunga, umur panen, jumlah buah per tanaman, panjang serat dan bobot kapas berbiji. Analisis karakter kualitatif menggunakan daftar deskriptor kapas. Analisis karakter kuantitatif menggunakan program SPSS untuk menganalisis regresi dan korelasi. Sedangkan untuk uji lanjutnya menggunakan analisis BNJ $5 \%$ dengan rumus, sebagai berikut:

$$
\omega=\mathrm{q}_{\alpha}(\mathrm{P}, \mathrm{V}) \sqrt{\frac{K T G}{r}}
$$

\section{Keterangan:}

$$
\begin{array}{ll}
\omega & =\text { Nilai Tukey (HSD) } \\
\mathrm{q} & =\text { nilai table } \\
\mathrm{P} & =\text { perlakuan } \\
\mathrm{V} & =\text { derajat bebas } \\
\mathrm{KTG} & =\text { Kuadrat Tengah Galat } \\
\mathrm{r} & =\text { jumlah ulangan }
\end{array}
$$

Data dianalisa menggunakan analisa regresi sederhana dengan persamaan:

$$
Y=a+b X
$$

Keterangan:

$\mathrm{Y}=$ Karakter terikat

$\mathrm{a}=$ Konstanta

$\mathrm{b}=$ Koefisien regresi

$\mathrm{X}=$ Karakter bebas

Kemudian, dilanjutkan dengan melakukan analisis korelasi menggunakan rumus :

$$
r(x i y)=\frac{\operatorname{Cov} x i y}{\sqrt{(\operatorname{var} x i)(\operatorname{var} y)}}
$$

Keterangan:

$r(x i y)=$ Nilai koefisien korelasi

\section{HASIL DAN PEMBAHASAN}

\section{Analisis Regresi dan Korelasi}

Berdasarkan hasil analisa regresi dan korelasi yang telah dilakukan, terdapat enam karakter yang telah diobservasi memiliki keeratan hubungan positif dan nyata yang disajikan pada Tabel 1 . Nilai 
koefisien regresi dan korelasi positif dan nyata untuk karakter tinggi tanaman terhadap jumlah buah $(\mathrm{b}=0,110$ dan $\mathrm{r}=$ 0,406). Jumlah cabang vegetatif, memiliki nilai regresi dan korelasi positif nyata terhadap jumlah buah $(\mathrm{b}=11,848$ dan $\mathrm{r}=$ 0,576). Jumlah cabang generatif memiliki nilai regresi dan korelasi positif nyata terhadap jumlah buah $(\mathrm{b}=1,839$ dan $\mathrm{r}=$ $0,669)$ dan bobot kapas berbiji $(b=2,783$ dan $r=0,414)$. Jumlah buah memiliki nilai regresi dan korelasi posistif dan nyata terhadap karakter bobot kapas berbiji $(\mathrm{b}=$ $1,875$ dan $r=0,739)$. Berbeda halnya dengan karakter jumlah bulu daun menunjukkan nilai regresi dan korelasi negatif dan nyata terhadap panjang serat (b $=-0,002$ dan $r=-0,458)$.

Karakter yang memiliki nilai koefisien korelasi yang tinggi dan kuat terhadap komponen hasil yaitu pada karakter jumlah buah $(r=0,739)$ dan jumlah cabang generatif $(\mathrm{r}=0,414)$. Hal ini membuktikan bahwa semakin meningkatnya jumlah cabang generatif dan jumlah buah pada setiap aksesi kapas akan diikuti dengan peningkatan komponen hasil dalam hal ini yaitu karakter bobot kapas berbiji. Karakter jumlah cabang generatif dan jumlah buah menunjukkan hubungan yang erat dan kuat ditandai dengan nilai koefisien korelasi yang positif dan nyata $(r$ $=0,669)$. Hal ini membuktikan bahwa semakin meningkatnya jumlah cabang generatif akan diikuti dengan peningkatan jumlah buah. Rizqiyah et al., (2014) melaporkan bahwa karakter jumlah polong per tanaman dan bobot per polong tanaman buncis dapat digunakan sebagai karakter perbaikan sifat karena memiliki korelasi positif sangat nyata dan pengaruh langsung positif yang lebih baik terhadap komponen hasil.

Koefisien regresi untuk kedua karakter tersebut menunjukkan adanya bentuk hubungan positif dan tingkat ketelitian yang tinggi. Umufatdilah dan Adiredjo (2019) melaporkan bahwa karakter yang memiliki nilai koefisien regresi dan korelasi yang kuat menunjukkan adanya hubungan yang erat dan tingkat ketelitian yang tinggi. Hal tersebut didukung oleh Rahman et al. (2013) yang menyatakan bahwa jumlah buah per tanaman memiliki korelasi positif nyata yang kuat dengan bobot kapas berbiji per tanaman. Azis et al. (2017) menyatakan bahwa karakter bobot umbi, biomassa tanaman, diameter umbi, dan tinggi tanaman memiliki hubungan yang erat yang ditandai dengan adanya korelasi positif terhadap karakter bobot umbi. Penelitian Khalid et al. (2018), menyebutkan bahwa jumlah buah per tanaman berkorelasi positif dengan bobot kapas berbiji.

Tinggi tanaman nyata menunjukkan hubungan linear positif terhadap karakter hasil yaitu jumlah buah $\left(\mathrm{R}^{2}=0,165\right)$ artinya $16,5 \%$ variasinya disebabkan oleh tinggi 
tanaman. Jumlah cabang vegetatif nyata menunjukkan hubungan linear positif terhadap karakter jumlah buah $\left(\mathrm{R}^{2}=0,332\right)$ artinya $33,2 \%$ variasinya disebabkan oleh jumlah cabang vegetatif. Jumlah cabang generatif nyata menunjukkan hubungan linear positif terhadap karakter jumlah buah $\left(\mathrm{R}^{2}=0,428\right)$ artinya $42,8 \%$ variasinya disebabkan oleh jumlah cabang generatif. Grafik pada Gambar 1 menunjukkan bentuk dan arah hubungan positif antar variabel terkait.

Tabel 1. Koefisien Korelasi (r), koefisien determinasi $\left(\mathrm{R}^{2}\right)$, Koefisien regresi (b) dan signifikansi komponen hasil terhadap hasil kapas

\begin{tabular}{lrrrl}
\hline \multicolumn{1}{c}{ Kombinasi Karakter } & \multicolumn{1}{c}{$\mathrm{r}$} & \multicolumn{1}{c}{$\mathrm{R}^{2}$} & $\mathrm{~b}$ & Sig.(b) \\
\hline Tinggi tanaman dan jumlah buah & 0,406 & 0,165 & 0,110 & $\mathrm{n}$ \\
Tinggi Tanaman dan panjang serat & $-0,333$ & 0,111 & 0,007 & $\mathrm{tn}$ \\
Tinggi Tanaman dan bobot kapas berbiji & 0,123 & 0,015 & 0,079 & $\mathrm{tn}$ \\
Jumlah cabang vegetatif dan jumlah buah & 0,576 & 0,332 & 11,848 & $\mathrm{n}$ \\
Jumlah cabang vegetatif dan panjang serat & $-0,253$ & 0,064 & $-0,404$ & tn \\
Jumlah cabang vegetatif dan bobot kapas berbiji & 0,309 & 0,095 & 15,472 & tn \\
Jumlah cabang generatif dan jumlah buah & 0,669 & 0,428 & 1,839 & $\mathrm{n}$ \\
Jumlah cabang generatif dan panjang serat & $-0,125$ & 0,016 & $-0,027$ & tn \\
Jumlah cabang generatif dan bobot kapas berbiji & 0,414 & 0,172 & 2,783 & $\mathrm{n}$ \\
Jumlah bulu daun dan jumlah buah & 0,328 & 0,108 & 0,016 & tn \\
Jumlah bulu daun dan panjang serat & $-0,458$ & 0,210 & $-0,002$ & $\mathrm{n}$ \\
Jumlah bulu daun dan bobot kapas berbiji & $-0,010$ & 0,000 & $-0,001$ & tn \\
Umur awal berbunga dan jumlah buah & 0,088 & 0,008 & 0,201 & tn \\
Umur awal berbunga dan panjang serat & $-0,071$ & 0,005 & $-0,013$ & tn \\
Umur awal berbunga dan bobot kapas berbiji & 0,010 & 0,000 & 0,055 & tn \\
Umur panen dan jumlah buah & 0,381 & 0,145 & 0,203 & tn \\
Umur panen dan panjang serat & 0,179 & 0,032 & 0,019 & tn \\
Umur panen dan bobot kapas berbiji & 0,141 & 0,020 & 0,467 & tn \\
Jumlah buah dan panjang serat & 0,075 & 0,006 & 0,006 & tn \\
Jumlah buah dan bobot kapas berbiji & 0,739 & 0,546 & 1,875 & $\mathrm{n}$ \\
Panjang serat dan bobot kapas berbiji & 0,341 & 0,116 & 10,648 & tn \\
\hline Keterangan : n Nyata
\end{tabular}

Keterangan $: \mathrm{n}=$ Nyata; $\mathrm{tn}=$ Tidak nyata.

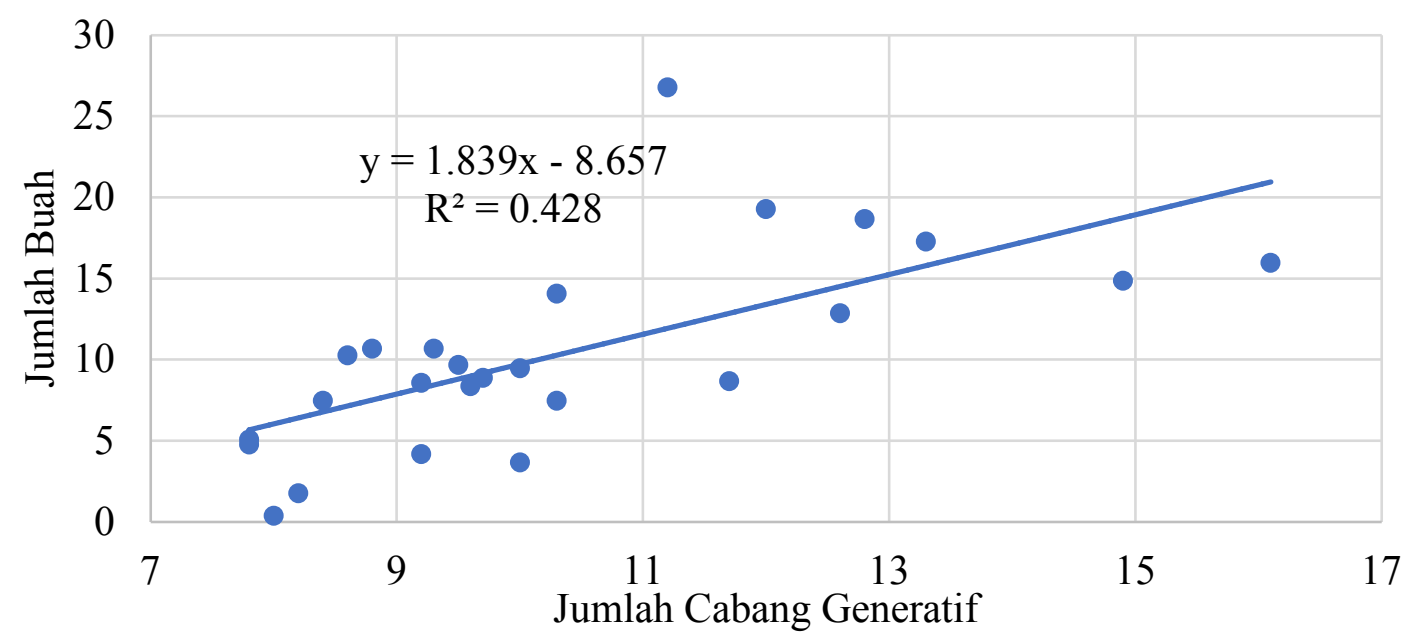

Gambar 1. Grafik regresi jumlah cabang generatif dan jumlah buah 


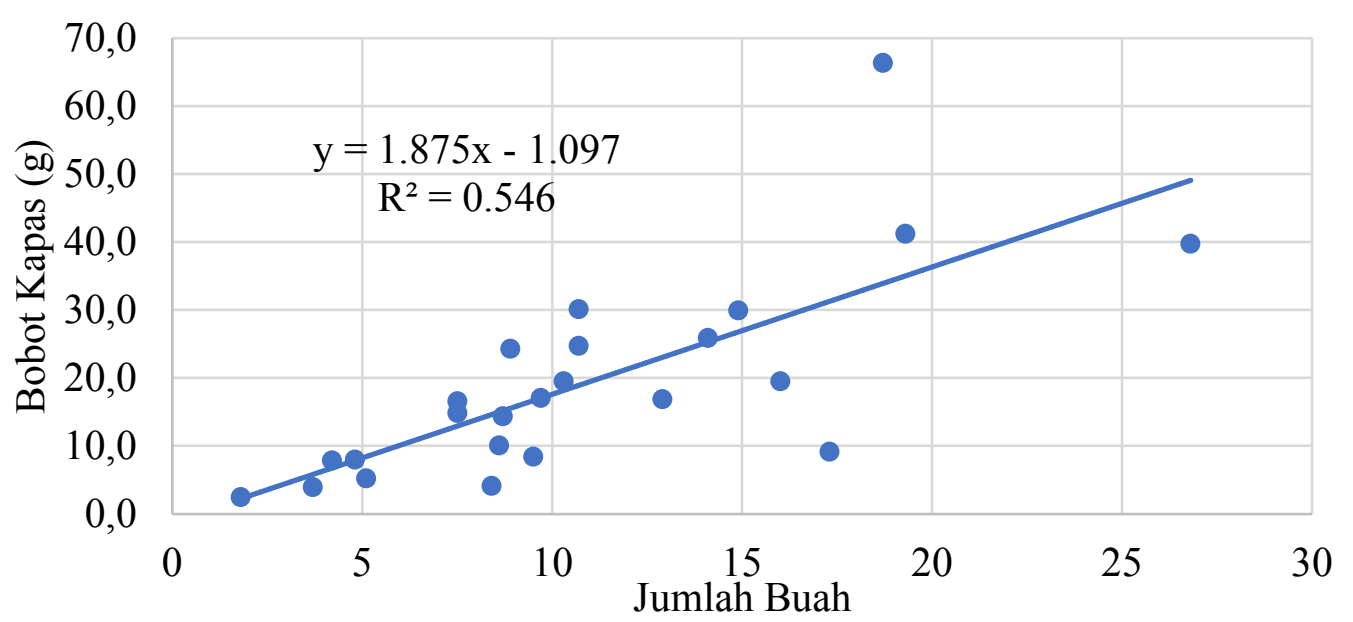

Gambar 2. Grafik regresi jumlah buah terhadap bobot kapas berbiji

Karakter jumlah cabang menunjukkan hubungan linear positif terhadap bobot kapas berbiji $\left(\mathrm{R}^{2}=0,172\right)$ artinya $17,2 \%$ variasinya disebabkan oleh jumlah cabang generatif. Koefisien regresi $(b=2,783)$ menunjukkan bahwa dalam setiap peningkatan satu unit jumlah cabang generatif, terdapat peningkatan bobot kapas berbiji sebesar 2,783 gram/tanaman. Cabang generatif yang akan menghasilkan buah lebih banyak dibandingkan cabang vegetatif. Hal tersebut dikarenakan jumlah cabang generatif yang lebih banyak, sehingga jumlah buah yang dihasilkan juga akan semakin banyak. Hal tersebut sesuai didukung oleh Salahuddin et al. (2010), bahwa peningkatan unit cabang simpodial per tanaman akan meningkatkan hasil kapas berbiji per tanaman. Jumlah cabang yang banyak maka akan diperoleh hasil polong isi tanaman kedelai yang lebih tinggi (Wijayati et al., 2014).

\section{Evaluasi Karakter Morfologi Tanaman Kapas}

Karakter morfologi merupakan semua karakter yang dapat diamati pada tanaman kapas. Evaluasi karakter morfologi ditekankan pengaruhnya terhadap daya hasil. Karakter kualitatif yang diamati ialah bentuk tanaman, warna batang, bentuk daun, warna petal, bentuk buah, bentuk ujung buah, warna buah, warna serat dan warna fuzz. Tabel 2 menunjukkan karakter morfologi tanaman yang terdiri dari bentuk tanaman, warna batang, bentuk daun dan warna petal.

Berdasarkan Tabel 2, karakter bentuk tanaman didominasi bentuk conical, sebagian bentuk globose dan cylindrical. Penelitian Feng et al. (2016) menunjukkan bahwa tanaman kapas yang memiliki bentuk pagoda/conical dengan daun normal memiliki indek luas daun dan kandungan klorofil lebih tinggi dibandingkan bentuk tanaman cylindrical berdaun normal,

Tabel 2. Karakter morfologi bentuk tanaman, warna batang, bentuk daun dan warna petal 


\begin{tabular}{|c|c|c|c|c|}
\hline Kode Aksesi & $\begin{array}{c}\text { Bentuk } \\
\text { Tanaman }\end{array}$ & Warna Batang & Bentuk Daun & Warna Petal \\
\hline Kanesia 19 & Cylindrical & Hijau Kemerahan & Palmate & Krem \\
\hline KI 5 & Conical & Hijau Kemerahan & Palmate & Krem \\
\hline KI 38 & Conical & Hijau Kemerahan & Palmate & Krem \\
\hline KI 42 & Conical & Hijau Kemerahan & Palmate & Krem \\
\hline KI 80 & Globose & Hijau Muda & Digitate & Krem \\
\hline KI 95 & Globose & Hijau Kemerahan & Palmate & Krem \\
\hline KI 106 & Conical & Hijau Kemerahan & Palmate & Krem \\
\hline KI 109 & Conical & Hijau Kemerahan & Palmate & Krem \\
\hline KI 124 & Conical & Hijau Kemerahan & Digitate & Krem \\
\hline KI 134 & Conical & Hijau Kemerahan & Palmate & Krem \\
\hline KI 188 & Conical & Hijau Tua & Palmate to digitate & Krem \\
\hline KI 225 & Conical & Hijau Kemerahan & Palmate & Krem \\
\hline KI 240 & Conical & Hijau Kemerahan & Palmate & Kuning \\
\hline KI 241 & Conical & Hijau Kemerahan & Palmate & Krem \\
\hline KI 286 & Conical & Hijau Kemerahan & Digitate & Krem \\
\hline KI 301 & Conical & Hijau Tua & Digitate & Kuning \\
\hline KI 320 & Conical & Hijau Kemerahan & Palmate & Krem \\
\hline KI 489 & Conical & Hijau Kemerahan & Palmate & Krem \\
\hline KI 494 & Conical & Hijau Kemerahan & Palmate & Krem \\
\hline KI 500 & Globose & Hijau Kemerahan & Digitate & Krem \\
\hline KI 502 & Cylindrical & Hijau Kemerahan & Palmate & Krem \\
\hline KI 629 & Conical & Hijau Muda & Palmate & Krem \\
\hline KI 689 & Conical & Hijau Kemerahan & Palmate & Kuning \\
\hline KI 693 & Conical & Hijau Kemerahan & Palmate & Krem \\
\hline KI 711 & Conical & Hijau Kemerahan & Palmate & Kuning \\
\hline
\end{tabular}

bentuk tanaman kompak berdaun normal dan bentuk tanaman inverted-cone berdaun okra. Bentuk conical berdaun normal dapat mengoptimalkan ruang untuk cahaya dan memaksimalkan intersepsi cahaya, sehingga meningkatkan kemampuan fotosintesis yang dapat mempengaruhi hasil tanaman menjadi lebih optimal. Karakter warna batang didominasi warna hijau kemerahan, sebagian warna hijau muda, hijau tua dan merah. Pkania (2016), menyatakan bahwa tanaman kapas berwarna merah signifikan tidak disukai hama kutu daun kapas (Aphis gossypii).
Bentuk daun aksesi kapas didominasi bentuk palmate yang juga dimiliki varietas Kanesia 19, sebagian digitate dan palmate to digitate. Menurut Andres et al. (2016), bentuk daun digitate, memiliki efek positif terhadap penetrasi semprotan kimia, mengurangi jumlah boll yang membusuk dan lebih cepat memasuki fase generatif tingkat pembungaan. Bentuk daun palmate to digitate sebanding dengan palmate dalam sebagian besar ciri, yang berperan dalam peningkatan retensi boll dan hasil. Kultivar kapas yang ideal akan menghasilkan daun normal sampai titik penutupan kanopi dan 
Tabel 3. Karakter morfologi bentuk buah, bentuk ujung buah, warna buah, warna serat dan warna fuzz

\begin{tabular}{|c|c|c|c|c|}
\hline Kode Aksesi & Bentuk Buah & Bentuk Ujung Buah & Warna Buah & Warna Serat \\
\hline Kanesia 19 & Conical & Medium & Hijau & Putih \\
\hline KI 5 & Ovate & Medium & Hijau & Putih \\
\hline KI 38 & Ovate & Medium & Hijau & Putih \\
\hline KI 42 & Ovate & Medium & Hijau & Bukan Putih \\
\hline KI 80 & Ovate & Strong & Hijau & Putih \\
\hline KI 95 & Ovate & Strong & Hijau & Putih \\
\hline KI 106 & Ovate & Medium & Hijau & Putih \\
\hline KI 109 & Ovate & Strong & Hijau & Putih \\
\hline KI 124 & Ovate & Weak & Merah Kehijauan & - \\
\hline KI 134 & Ovate & Strong & Hijau & Putih \\
\hline KI 188 & Conical & Medium & Hijau & Putih \\
\hline KI 225 & Ovate & Strong & Hijau & Putih \\
\hline KI 240 & Elliptical & Medium & Hijau & Putih \\
\hline KI 241 & Ovate & Weak & Hijau & Putih \\
\hline KI 286 & Rounded & Strong & Merah & Putih \\
\hline KI 301 & Conical & Weak & Hijau & Putih \\
\hline KI 320 & Conical & Medium & Hijau & Putih \\
\hline KI 489 & Ovate & Medium & Hijau & Putih \\
\hline KI 494 & Ovate & Strong & Hijau & Putih \\
\hline KI 500 & Ovate & Strong & Hijau & Putih \\
\hline KI 502 & Conical & Medium & Merah Kehijauan & Bukan Putih \\
\hline KI 629 & Ovate & Strong & Hijau & Putih \\
\hline KI 689 & Elliptical & Medium & Hijau & Putih \\
\hline KI 693 & Conical & Strong & Hijau & Putih \\
\hline KI 711 & Elliptical & Medium & Hijau & Putih \\
\hline
\end{tabular}

akan beralih ke kanopi terbuka okra atau super okra. Menurut Pkania (2016), tanaman dengan bentuk daun okra memiliki kanopi terbuka yang memungkinkan sirkulasi cahaya dan udara lebih baik dan memungkinkan berkurangnya populasi hama Pectinophora gossypiela.

Warna petal aksesi kapas didominasi putih, sebagian kuning, putih kemerahan dan merah. Varietas Kanesia 19 memiliki warna petal putih. Penelitian, warna bunga kapas disebabkan efek flavonol dan antosianin yang merupakan flavonoid utama yang ditemukan pada bunga kapas.
Berkurangnya flavonol akan membuat hilangnya warna pigmen pada petal. Kandungan antosianin ditemukan paling tinggi pada bunga kapas warna merah, diikuti bunga warna putih dan kuning. Flavonoid berperan menarik serangga dan untuk perlindungan sinar ultraviolet.

Karakter bentuk buah, ujung buah, warna buah, warna serat dan warna fuzz ditunjukkan pada Tabel 3. Karakter bentuk buah didominasi bentuk ovate, sebagian bentuk conical, elliptical dan rounded. Bentuk ujung buah didominasi medium, diikuti bentuk strong dan weak. Warna buah 
didominasi warna hijau, sebagian warna hijau kemerahan dan warna merah. Varietas Kanesia 19 memiliki bentuk buah conical dengan bentuk ujung buah medium berwarna hijau.

Warna serat kapas didominasi warna putih yang juga dimiliki varietas Kanesia 19, satu aksesi warna coklat terang dan satu aksesi warna serat coklat gelap. Akumulasi flavonoid dan ekspresi gen struktural flavonoid lebih tinggi pada serat kapas coklat dibandingkan serat kapas putih (Feng et al., 2013). Menurut Tan et al. (2013), flavonoid berperan dalam pengembangan serat dan mempengaruhi kualitas serat yang dihasilkan (panjang serat dan micronaire). Serat lebih pendek terdapat pada kapas dengan flavonone (bagian dari flavonoid) tinggi. Sehingga warna serat kapas putih cenderung memiliki mutu serat baik pada karakter panjang serat. Warna fuzz didominasi warna putih, sebagian coklat muda dan terdapat tiga aksesi yang tidak memiliki fuzz. Varietas Kanesia 19 memiliki fuzz berwarna putih. Menurut Supriyanto et al. (2007), biji kapas yang masih diselimuti serat-serat kapas pendek disebut biji kapas berkabu, sulit untuk dilakukan sortasi, penyimpanan dan pemberian fungisida. Berdasarkan hasil penelitian, aksesi kapas yang tidak memiliki fuzz langsung terlepas dari serat. Biji yang masih memiliki fuzz dapat dilakukan proses delinting (pembersihan serat pendek biji) dengan asam sulfat.

Berdasarkan hasil evaluasi, karakter morfologi kapas yang bersifat kualitatif menunjukkan karakter unggul untuk perbaikan produksi ialah bentuk tanaman conical, warna batang merah, bentuk daun digitate dan warna serat putih. Berdasarkan karakter kuantitatif dipilih aksesi berproduksi tinggi melalui karakter unggul jumlah cabang generatif dan jumlah buah sekaligus memiliki kualitas mutu serat baik melalui karakter unggul panjang serat. Kanesia 19 mewakili genotipe dengan produksi tinggi dan memiliki kriteria panjang serat yang diterima industri tekstil minimal memiliki panjang 1,08 inchi. Berdasarkan evaluasi, diperoleh 11 aksesi yang memiliki kedua karakter unggul yang bersifat kualitatif dan kuantitatif, yang direkomendasikan sebagai tetua kapas berproduksi tinggi yang memiliki mutu serat baik, yaitu aksesi KI 38, KI 80, KI 134, KI 240, KI 320, KI 489, KI 500, KI 629, KI 689, KI 693 dan KI 711.

\section{KESIMPULAN}

Kriteria seleksi pada analisis korelasi dan regresi komponen hasil dapat dilihat melalui keeratan hubungan yang nyata dan memiliki bentuk linier positif. Jumlah cabang generatif dan jumlah buah dapat digunakan sebagai karakter seleksi untuk memperoleh aksesi kapas yang berproduksi 
tinggi dan bermutu serat baik. Aksesi KI 38, KI 240, KI 689, KI 693 dan KI 711 memiliki keunggulan produksi tinggi melalui jumlah cabang generatif, jumlah buah yang tinggi dan bentuk tanaman conical, serta kualitas mutu serat melalui panjang serat dan warna serat putih. Aksesi KI 320, KI 489, KI 500 dan KI 629 memiliki keunggulan produksi tinggi ditunjukkan melalui jumlah cabang generatif dan bentuk tanaman conical serta kualitas mutu serat melalui panjang serat dan warna serat putih. Aksesi KI 80 dan KI 500 memiliki keunggulan produksi tinggi ditunjukkan melalui jumlah cabang generatif dan bentuk daun digitate serta kualitas mutu serat melalui panjang serat dan warna serat putih. Aksesi KI 134 memiliki keunggulan produksi tinggi ditunjukkan melalui jumlah cabang generatif, bentuk tanaman conical dan warna batang merah serta kualitas mutu serat melalui panjang serat dan warna serat putih.

\section{UCAPAN TERIMA KASIH}

Penulis mengucapkan terima kasih kepada Ir. Siwi Sumartini dan Dr. Ir. Marjani, MP atas saran dan bimbingannya selama kegiatan penelitian dilaksanakan.

\section{DAFTAR PUSTAKA}

Abdi, A., T. Wright, dan S. Meylinah. 2017. Indonesia Cotton and Products
Annual Report 2017. Global Agricultural Information Network. Jakarta.

Andres, R.J., D.T. Bowman, D.C. Jones, and V. Kuraparthy. 2016. Major leaf shapes of cotton: genetics and agronomic effects in crop production. Journal of Cotton Science, 20(4): 330-340.

Azis, F.N., R. Budiono, dan S.S. Zunaini. 2017. Keragaman dan keeratan hubungan komponen hasil bawang merah kultivar super philip di sembilan pemupukan. Jurnal Agrin, 21(1): 11-16.

Björquist, S., J. Aronsson, G. Henriksson, and A. Persson. 2018. Textile qualities of regenerated cellulose fibers from cotton waste pulp. Textile Research Journal, 88(21): 24852492.

Direktorat Jenderal Perkebunan. 2016. Statistik Perkebunan Indonesia 20152017 Kapas (D.D. Hendaryati and Y. Arianto, editors). 1st ed. Sekretariat Direktorat Jenderal Perkebunan. Jakarta.

Feng, G., H. Luo, Y. Zhang, L. Gou, Y. Yao, Y. Lin, W. Zhang. 2016. Relationship between plant canopy characteristics and photosynthetic productivity in diverse cultivars of cotton (Gossypium hirsutum L.). The Crop Journal, 4(6): 499-508.

Feng, H., X. Tian, Y. Liu, Y. Li, X. Zhang, B.J. Jones, Y. Sun, J. Sun. 2013. Analysis of flavonoids and the flavonoid structural genes in brown fiber of upland cotton (J. Zhang, editor). Journal Plos One, 8(3): 1-10.

Indrayani, I., dan S. Sumartini. 2012. Pengaruh kerapatan bulu daun dan kelenjar gosipol terhadap infestasi hama pengisap daun Amrasca biguttula Ishida dan penggerek buah Helicoverpa armigera Hubner pada kapas. Jurnal Penelitian Tanaman 
Industri, 18(3): 95-101.

Khalid, M.A., T.A. Malik, N. Fatima, A. Shakeel, I. Karim, M. Arfan, S. Merrium, and P. Khanum. 2018. Correlation for economic traits in upland cotton. ACTA Scientific Agriculture, 2(10): 59-62.

Kulaz, H. 2012. Relationships among yield components and selection criteria for seed yield improvement in bush bean (Phaseolus vulgaris L.). Journal Agricultural Science, 18(4): 257-262.

Kusuma, J., dan M. Tahir. 2016. Evaluasi karakter pertumbuhan dan inflorescence plasma nutfah kapas introduksi dan lokal pada iklim tropis. Jurnal Penelitian Pertanian Terapan, 16(3): 205-211.

Lelang, M.A. 2017. Uji korelasi dan analisis lintas terhadap karakter komponen pertumbuhan dan karakter hasil tanaman tomat (Lycopersicum esculentum Mill). Jurnal Pertanian Konservasi Lahan Kering Savana Cendana, 2(02): 33-35.

Mahajan, R, P.Wadikar, S.Pole, and M.Dhuppe. 2011. Variability, correlation and path analysis studies in sorghum. Reseach Journal of Agricltural Sciences, 2(1): 101-103.

Novrika, D., dan C. Herison. 2016. Korelasi antar komponen pertumbuhan vegetatif dan generatif dengan hasil pada delapan belas genotipe gandum di dataran tinggi. Jurnal Akta Agrosia, 19(2): 93-103.

Nurnasari, E., dan Nurindah. 2017. Karakteristik kimia serat buah, serat batang, dan serat daun. Buletin Tanaman Tembakau, Serat, Minyak Industri, 9(2): 64-72.

Permata, S., Taryono, dan M.. Suyadi. 2015. Hubungan antara komponen hasil dan hasil wijen (Sesamun Indicum L.). Jurnal Vegetalika, 4(2): 112-123.
Pkania, K.C. 2016. Genetic Diversity Of Cotton and Bacterial Blight (Xanthomonas citri pv. malvacearum) Prevalence in Western Kenya. PhD Thesis. Ghent University, Belgium.

Prabowo, H., dan D.W. Djoar. 2014. Korelasi sifat-sifat agronomi dengan hasil dan kandungan antosianin padi beras merah. Jurnal Agrosains, 16(2): 49-54.

Pusdatin. 2015. Outlook Kapas Komoditas Pertanian Subsektor Perkebunan (L. Nuryati dan Novianti, editors). 1st ed. Sekretariat Direktorat Jenderal Pertanian, Jakarta.

Rahman, S.A., M. Riaz, R. Shahid, J. Farooq, M. Shahid, A. Mahmood, G. Abbas. 2013. Cause and effect estimates for yield contributing and morphological traits in upland cotton (Gossypium hirsutum L.). Jurnal of Agricultural Research, 51(4): 393398.

Rizqiyah, D.A., N. Basuki, dan A. Soegianto. 2014. Hubungan antara hasil dan komponen hasil pada tanaman buncis (Phaseolus vulgaris L.) generasi F2. Jurnal Produksi Tanaman, 2(4): 330-338.

Salahuddin, S., S. Abro, A. Rehman, and K. Iqbal. 2010. Correlation analysis of seed cotton yield with some quantitative traits in upland cotton (Gossypium hirsutum L.). Pakistan Journal of Botany, 42(6): 3799-3805.

Sumartini, S., I. Indrayani, dan Abdurrakhman. 2010. Skrining genotipe kapas (Gossypium sp.) umur genjah berdaya hasil tinggi. Jurnal Penelitian Tanaman Industri, 16(1): 27-36.

Supriyanto, P. Widodo, dan M. Sahid. 2007. Rancang bangun alat pembersih serat pendek (kabu-kabu) biji kapas tipe kering pada prosessing benih kapas (delinter). Jurnal Agritech., 27(4): 176-181. 
Tan, J., M. Wang, L. Tu, Y. Nie, Y. Lin, X. Zhang. 2013. The flavonoid pathway regulates the petal colors of cotton flower (J. Zhang, editor). Journal Plos One. 8(8): 1-9.

Umufatdilah, E., dan A.L. Adiredjo. 2019. Analisa regresi dan korelasi beberapa karakter tanaman kenaf (Hibiscus cannabibus L.) generasi F2 hasil persilangan varietas $\mathrm{HC} 48$ dan SM004. Jurnal Produksi Tanaman, 7(4): 637-642.

Wijayati, R.Y., S. Purwanti, dan M.M.
Adie. 2014. Hubungan hasil dan komponen hasil kedelai (Glycine max (L.) Merr.) populasi F5. Jurnal Vegetalika, 3(4): 88-97.

Yamin, M. 2014. Pendugaan Komponen Ragam Karakter Agronomi Gandum (Triticum aestivum L.) dan Identifikasi Marka Simple Sequence Repeat (SSR) Terpaut Suhu Tinggi Menggunakan Bulk Segregant Analysis (BSA). Tesis. Sekolah Pasca Sarjana. Institut Pertanian Bogor, Bogor. 87 Hal. 